\title{
Role of Allopathic Medicines in Ulcers
}

\author{
Shubham Pasahan ${ }^{*}$, Pooja Sharma ${ }^{1,2}$, Dinesh Kumar ${ }^{1}$ \\ ${ }^{1}$ Sri Sai College of Pharmacy, Manawala, Amritsar-143115, Punjab, India \\ ${ }^{2}$ Department of Pharmaceutical Sciences and Drug Research, Punjabi University Patiala
}

Address for Correspondence: Shubham Pasahan; shubhampashan@gmail.com

Received:

01.03.2019

Accepted:

25.03.2019

Keywords

Peptic ulcer,

Antiulcer,

Misoprostol,

Sucralfate,

Rabeprazole.
ABSTRACT: Peptic ulcer is erosion in the mucosal wall of the stomach or parts of small intestine called duodenum. For most patients sucralfate, rabeprazole, omeprazole etc. all the drugs of choice. Misoprostol, a synthetic methyl ester an analogue of prostaglandin E1 is both a powerful inhibitor of gastric secretions and is able to protect the gastro duodenal mucosa from damage produced by alcohol, aspirin, naproxen and tolmetin. The ideal aims of treatment of peptic ulcer disease are to relieve pain, heal the ulcer and delay its recurrence one large trial has shown that misoprostol is able to heal a significant proportion of duodenal ulcer refractory to treatment with $\mathrm{H} 2$ receptor antagonist, proton pump inhibitor, anti cholinergics and antacids, administration of misoprostol has been proven to be effective for both prevention and treatment of gastro duodenal ulcer associated with Non-steroidal anti-Inflammatory drugs NSAIDS therapy in arthritic patients, alcoholics, smokers and patients compelled to take these drugs for longer periods. Misoprostol is therefore, a safe and effective drug in this treatment as it also resulted in reduction of associated complications of NSAIDS such as perforation, stenosis, bleeding occurs. It protects gastric mucosa by decreasing gastric acid secretions, increasing mucosa and bicarbonate production. Another advantage include induction of labour for termination pregnancy disadvantage in atonic uterus and its rupture. The important side effects include abdominal pain flatulence and diarrhea. The relocation of hydroxy group has induced changes of diarrhea has emerged as a major drug for the treatment of peptic ulcer as anti ulcer drug. () 2019 iGlobal Research and Publishing Foundation. All rights reserved.

Cite this article as: Pasahan, S.; Sharma, P.; Kumar, D. Role of Allopathic Medicines in Ulcers. Indo Global J. Pharm. Sci., 2019; 9(2Suppl.): 142. DOI: http://doi.org/10.35652/IGJPS.2019.92S40 .

Indo Global Journal of Pharmaceutical Sciences( ISSN 2249 1023; CODEN- IGJPAI; NLM ID: 101610675) indexed and abstracted in CrossRef (DOI Enabling), UGC CARE Journal List, EMBASE(Elsevier), National Library of Medicine (NLM) Catalog, ResearchGate, Publons, CAS (ACS), Index Copernicus, Google Scholar and many more. For further details, visit http://iglobaljournal.com

This is a special issue as an outcome of 'RAPSCON-2019' sponsored by APTI and organized by Sri Sai College of Pharmacy, Manawala, Amritsar, Punjab, India. Relaxation offered in journal format. 